\title{
Children's Right to Play and Its Implementation: A Comparative, International Perspective
}

\author{
Andrés Payà Rico ${ }^{1} \odot$ and Jaume Bantulà Janot ${ }^{2} \odot$ \\ ${ }^{1}$ Department Comparative Education and History of Education, University of Valencia, Spain \\ ${ }^{2}$ School of Psychology, Education and Sport Sciences, University of Ramon Llull, Spain
}

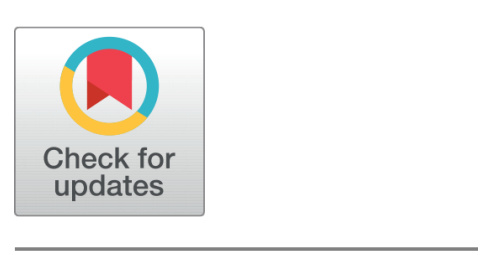

Received 2020-10-15

Revised 2020-10-19

Accepted 2020-12-02

Published 2021-07-15

Corresponding Author

Andrés Payà Rico,

andres.paya@uv.es

Departamento de Educación Comparada e Historia de la Educación, Facultad de Filosofía y Ciencias de la Educación, Avenida Blasco Ibañez 30, 46010, Valencia, Spain.

DOI https://doi.org/10.7821/

naer.2021.7.665

Pages: 279-294

Funding: Ministry of Economy and Competitiveness, Spain (Award:EDU2014-52268-P)

Distributed under

Creative Commons CC BY 4.0

Copyright: (C) The Author(s)

\section{OPEN ACCESS}

\section{ABSTRACT}

The child's right to play is specifically addressed in the framework of the Convention on the Rights of the Child. The international recognition of this right is the central theme of this study. Through a documentary analysis of the reports of the States Parties to the Convention and the Concluding Observations of the Committee on the Rights of the Child, the study assesses the recognition of this right. The entry into force of General Comment 17 on the right of the child to rest, recreation, play, recreational activities, cultural life and the arts (art. 31) in 2013 should have marked a turning point in policies on children in the States Parties, but this did not occur. Policies cannot be developed in favour of children where play is ignored. Identifying the difficulties in exercising this right is also a challenge. Play should be part of the objectives, goals and strategies of action plans for children.

\section{Keywords CHILDHOOD, PLAY, RIGHTS OF THE CHILD, CHILD WELFARE,} COMPARATIVE ANALYSIS

\section{INTRODUCTION}

During the first third of the $20^{\text {th }}$ century, different conferences held on child protection (Dávila \& Naya, 2006) laid the groundwork for subsequent international policies, which culminated in the Convention on the Rights of the Child, in which children became the subject of rights for the first time.

After having been laboriously drafted for one decade, the Convention was approved by the General Assembly in Resolution 44/25 dated 20 November 1989, and the signing and ratification or adhesion to the Convention was held in New York on 26 January 1990. The Convention entered into force on 2 September 1990 in conformance with the provisions contained in its article 49.

On 1 October 2015, Somalia ratified the Convention, and since then a total of 196 countries have adhered to this important multilateral commitment to protect the fundamental guarantees of childhood. Therefore, this is the human rights treaty that has been the most widely ratified in history. The United States is the only country that has yet to complete the 
process. Despite having signed it in 1995, it has not yet ratified the Convention; that is, it supports the rights described in the document but is not legally committed to abide by it.

In order for the rights of children to be meaningful, it is not enough for a state to accept or even ratify- the Convention on the rights of the Child. They must also put it into practice.

With the intention of keeping watch over the exercise of the rights of the child, in 1991 the Committee on the Rights of the Child (CRC) was established, a body made up of independent experts who oversee implementation of the Convention on the Rights of the Child by the States Parties.

As stated in its regulations, the Committee is headquartered in Geneva. It usually holds three periods of sessions per year. The sessions are comprised of a three-week plenary session. Previous to the period of sessions, a working group meets for one week.

Article 4 of the Convention stipulates that states must effectively implement the rights of the child by adopting any measures needed, using up to the maximum resources available to do so. Article 44 requires the States Parties to report to the Committee on the measures they are taking to make the rights of the child a reality.

Thus, all the States Parties have to submit periodic reports to the Committee on the way these rights are exercised. Initially, the states have to submit a two-year report after adhering to the Convention, and later they must submit reports every five years. The Committee examines each report and expresses its concerns and recommendations to the States Parties in the guise of Final Observations.

The reports must mention the measures that the States Parties have adopted to implement the rights listed in the Convention and the progress made in terms of enjoyment of these rights. They should also indicate any circumstances and difficulties, if applicable, that affect the degree of compliance with the main obligations of the Convention. Therefore, the reports must contain enough information for the Committee to gain an overall understanding of the implementation of the Convention in that country.

The first periodic reports started in 1992. By the $71^{\text {st }}$ session of the Committee on the Rights of the Child held on 29 January 2016, the Committee had received 493 reports in conformance with article 44 of the convention, including 198 initial reports and 295 periodic reports.

\subsection{Case Study: The Child's Right to Play}

The Article 31 of the Convention explicitly states that "States Parties recognize the right of the child to rest and leisure, to engage in play and recreational activities appropriate to the age of the child and to participate freely in cultural life and the arts" (Brooker \& Woodhead, 2013; Lester \& Russell, 2008).

We expressly wish to address this right by focusing attention exclusively on the child's right to play. As stated in UNICEF's Handbook for the Implementation of the CRC (Hodgkin and Newell, p. 469) "play" is arguably the most interesting in terms of childhood, in that it includes children's activities which are not controlled by adults and which do not necessarily conform to any rules. The concept of free play is tricky. Play is either free or it is not. In cities, where more and more children on the planet live and will continue to 
live, freedom and creativity of play cannot be conditioned or -even worse-curtailed for the sake of safety and the increasing tendency for parents to be overprotective (Bantulà \& Payà, 2020b; Canning, 2007; Little, Wyver, \& Gibson, 2011; Sandseter, 2007).

We are not going to dwell on the importance and benefits of play (Engel, 2015; Gleave \& Cole-Hamilton, 2012; Manwaring \& Taylor, 2007; Whitebread, 2012). It is well known that play is essential to the development, health and wellbeing of children (Ginsburg, 2007; Goldstein, 2012; Kernan, 2007; Milteer, Ginsburg, \& Mulligan, 2012; Navidi, 2016; Pramling \& Asplund, 2008; Sandberg \& Heden, 2011; Tonkin, 2014; White, 2012). As Moyles bemoaned (2010, p. 3), "the fact that we are still having to justify play's existence in children's cognitive, physical and social development seems incredible and appears to reflect an intransigence -even ignorance- on the part of policy makers and those who regulate the policies".

Play cannot be considered a luxury (Fronczek, 2009, p. 28) or a right which must be honoured once other rights of the child have been achieved. Quite to the contrary, play is an essential, integral component (Lester \& Russell, 2010) which reinforces the four principles of the CRC: non-discrimination, survival and development, ensuring the child's interests and participation (Meire, 2007).

We concur with the International Play Association (IPA, 2010, p. 3) when its report recognises that the child's right to play "is one of the least known, least understood and least recognised rights of childhood, and consequently it is one of the rights that is the most consistently ignored, undervalued and violated in today's world".

For this reason, in 2008 the IPA forged an alliance with seven international organisations in order to propose that the United Nations' Committee on the Rights of the Child (CRC) (2013) hold a discussion day and draft a General Observation on Article 31 in order to explain its significance and expand the responsibilities of the States Parties to the Convention in terms of compliance with this article.

With the intention of gathering information from all over the world, the IPA and its allies organised a World Consultation on Children's Right to Play. Between January and July 2010, consultations were held in Bangkok, Beirut, Johannesburg, Mexico City, Bombay, Nairobi, Sofia and Tokyo. Three hundred and fifty experts in child play participated in the consultation, along with more than 400 children. As stated in the report (IPA, 2010), a total of 115 infractions were identified to prove noncompliance with the child's right to play. At the same time, practical recommendations were developed for governments with regard to compliance with Article 31.

The work done by the IPA paid off, and in the $62^{\text {nd }}$ period of sessions held from 14 January to 1 February 2013, the Committee approved General Observation 17 (2013) on the right of the child to rest, leisure, play, recreational activities, cultural life and the arts (article 31) in $\mathrm{CRC} / \mathrm{C} / \mathrm{GC} / 17$.

In its introduction, the Committee expresses its concern with the States' lack of recognition of the rights contained in Article 31. It adds that "poor recognition of their significance in the lives of children results in lack of investment in appropriate provisions, weak or non-existent protective legislation and the invisibility of children in national and local- 
level planning. In general, where investment is made, it is in the provision of structured and orga-nized activities, but equally important is the need to create time and space for children to engage in spontaneous play, recrea-tion and creativity, and to promote societal attitudes that sup-port and encourage such activity."

The committee expressed its concern with inequality in the enjoyment of the rights cited in Article 31 by girls, poor children, children with disabilities, indigenous children and those belonging to minorities, among others.

Whether from rich or poor countries, children witness how child labour, household chores and the increasing demands of education are lowing the amount of time available to enjoy these rights.

Now that the questions concerning the States Parties in relation to the right of the child to play have been presented, this study continues by formulating several questions with the intention of ascertaining the degree of compliance with this right.

\subsection{Problem}

Is it possible to ascertain the degree to which article 31 of the Convention is applied from an international comparative per-spective?

Likewise, if the international community, via the Committee on the Rights of the Child, believed that it was necessary to give this right greater emphasis, we should ask whether the approval of GO No. 17 in 2013 has signalled a change in states' child policies. In other words, do the States Parties invest more dedication and effort into fostering and defending the child's right to play? It is essential to ascertain the impact on recognition of the child's right to play since GO No. 17 has entered into force. How is this right being exercised? Are there reports on the indicators proposed by the Committee? What measures are the States Parties taking to foster child's play in the family, school and social life?

\section{METHODS}

In order to answer these questions, we first reviewed the reports that the States Parties forwarded to the Committee on the Rights of the Child (CRC), as well as the Final Observations issued by this Committee to the States Parties, in which it tells them its opinion on the supposed advances and achievements cited by the states in their reports.

The second phase of the study analyses whether the reports as well as the Final Observations issued since the date on which GO No. 17 was approved contain more references to article 31 .

As is common practice in other comparative studies (UNICEF, 2004), and given the physical impossibility of examining all the reports and general observations of the 196 states that have ratified the Convention, in the first part of the study we chose a sample comprised of 41 countries. These countries belong to the European Union, or to the OECD if they do not belong to the EU. In this way, the reports issued by the States Parties to the CRC were reviewed, while the CRC's Final Observations to these same States Parties were also reviewed. The USA was excluded from the sample because, since it is an OECD member but 
has not ratified the Convention, it is not obligated to draw up reports or receive guidance from the CRC.

In the second part, the sample was comprised of all the countries that have issued a report to the CRC after GO No. 17 entered into force (April 2013) and up to 31 December 2017. The review includes 78 States Parties. The CRC's Final Observations for the States Parties on the periodic reports they submitted were also reviewed. The revision includes a total of 96 States Parties.

By reading the reports and Final Observations of the States Parties in the study sample, all the information related to the child's right to play was collected. To analyse the content of the document sources from a comparative, international perspective, three areas in which child's play occurs were established: family, school and social. At the same time, for each area, four attributes that define the child's right to play were established: play time, play space, play materials and playmates or players.

We intended to process the document information according to whether the state reported on the structural measures (legal, institutional and regulatory framework) or process (implementation of policies and action programmes) or whether it reported on the results obtained (achievements, level of implementation, exercise or violation of the right in practice). However, in many cases - as we shall see below- the States Parties do not clearly and precisely define the intentions and scope of their policies, thus hindering an evaluation of the recognition of this right (Bantulà \& Payà, 2020a).

\section{RESULTS}

The results are outlined distinguishing between the two time-phases in which the information was analysed.

\subsection{First Period of the Study: Reports and Final Observations Between 1992 and 2013}

From 1992 until the approval of General Observation No. 17, the 40 States Parties belonging to the EU and/or the OECD, sent a total of 111 reports to the CRC: 40 first reports, 37 second reports, 30 third reports and 4 fourth reports. Of all of these reports, $66.66 \%$ make no mention of the child's right to play.

During this same period (1992-2103), the 40 States Parties sent a total of 110 Final Observations to the CRC: 40 first observations, 37 second observations, 29 third observations and 4 fourth observations. The CRC made no reference to the child's right to play in $90 \%$ of the Final Observations.

We then proceeded to analyse the contents of the reports and the Final Observations in which references to the right being studied did appear.

First, based on the document analysis of the $33.33 \%$ of the reports which included references to the child's right to play, we should highlight the following issues:

- With just a handful of exceptions, the reports do not mention measures or actions in favour of play at home or in the family: 
- The report from Austria (1997) mentions the celebration of a children's festival which lasts all summer in Vienna, so that parents and children can play as a family in any of the 47 city parks. Likewise, another report from Austria (2004) mentions the publication of a brochure that uses multiple activities to promote family life and contact with nature in towns, nursery schools and schools.

- In the area of education, several States Parties describe different initiatives:

- The reports from Germany (2003), Canada (2003 and 2012) and Iceland (2002) associate play with the child's development, and children are encouraged to play the in school curricula. Likewise, in Sweden (1997), the learning objectives stress the importance of play and regard inspiring the children with plenty of time, spaces and materials for their games as an essential job. The report from Sweden (2004) states that preschools have to offer a safe environment, furthermore one also stimulates children to play and be active. It is essential to guarantee the child's right to put his or her own initiative, imagination and creativity into practice in an atmosphere of play and learning. Along the same lines, in the United Kingdom (2008), the Department of Education implements a programme for children aged 2 which focuses on constructive play in groups in order to develop the child's social development, improve their communication and language skills and stimulate their imagination through play. Furthermore, the educational system in Northern Ireland recognises that education is more effective when children learn through an enriched experience based on play.

- Ireland (1995) indicates that the local administrations have taken charge of building good playing fields in nursery schools. The Democratic People's Republic of Korea (2003) reports on the creation of special play and recreation rooms in more than 150 nursery schools and day care centres. The report from the Netherlands (2008) states that some schools have improved and adapted their buildings and sports and recreational facilities to ensure that they can be accessed and used by disabled students.

- The Democratic People's Republic of Korea (2008) explains how many schools organise traditional games. The children are encouraged to fly Korean kites, entertain themselves with swings and seesaws, jump rope and engage in other popular games.

- In terms of the social area, the reports contain a large number and wide range of different initiatives:

- There are countries whose governments recognise the importance of play. The United Kingdom (1999) states that high-quality facilities benefit the child's overall development. In its 2002 report, it mentions that the National Playing Fields Association (NPFA) is in charge of the dissemination, education, training and safety of play. The NPFA has four training headquarters for monitoring: it manages the National Play Information Centre (NPIC), which is the most important centre in the world specialising in child's play; it has a forum, the 
Play Safety Forum, whose publication "Playground Safety Guidelines" seeks a balance between risk and safety in play. In Sweden (2004), the report states that children can lose creativity and spontaneity if the forms of entertainment they are offered are organised in advance and are overly supervised and predefined. The report from Ireland (2005) mentions that it is the first country in the world to have a detailed national policy on play (Ready, Steady, Play: A National Play Policy). Spain (2009) indicates that one of the objectives of the Strategic National Childhood Plan is to foster the child's right to play, leisure and free time by creating appropriate, accessible and safe spaces.

- With regard to play in public space, there are several state initiatives which have enacted laws and measures taken to guarantee sites meant for children and youths. Thus, in Austria (1997 and 2004), the United Kingdom (1999), Spain (2001), Italy (2002), Germany (2003), Australia (2004), the Netherlands (2018) and Korea (2008), the urban planning regulations include the creation of lands set aside for play and recreation. At the same time, in some cases they also encourage children's participation in the planning of these spaces. Guaranteeing the safety of playgrounds in Spain (2001), United Kingdom (2002), Canada (2003) and Romania (2008) is also one of the states' concerns.

- Some countries, like Canada (1994), are aware that children's access to free-time facilities is unequal, especially for children who live in remote or rural communities. Belgium (2009) subsidises community programmes that plan play areas and free-time facilities with the goal of updating the dynamic of neighbourhood life and fostering encounters among generations and cultures.

- Germany (2003) has a special association to defend the child's right to play (Das Recht des Kindes auf Spiel). In Austria (2011), too, there are several associations which disseminate and promote play, such as the Game Centre (Spielebox) and the Institute for Free-time Education (Institut für Freizeitpädagogik, IFP). Italy (2010) mentions holding International Play Day on the $28^{\text {th }}$ of May since 2005, promoted by the National City and Play Association (Associazione nazionale Città in gioco - GioNa).

- Some countries show an interest in finding out children's opinions via surveys. The children (Germany, 2003; Ireland, 2005; United Kingdom, 2008; Italy, 2010) respond that they want more play areas and more opportunities for free time and social life. They view play and recreation as important aspects of their quality of life. The report from the Netherlands (2008) mentions that today, youths spend less free time in group activities in a public setting (on the street or on playgrounds) and more on individual activities in private settings.

- The reports from Spain (2009), Austria (2011) and Germany (2012) announce that they have accepted the new Pan European Game Information code.

- In Croatia (1994), Austria (2004), Spain (2009) and Iceland (2010), children and youths are banned from participating in gambling in which they bet money.

- The report from Croatia (1994) mentions that there are several playrooms in libraries, museums and theatres in Zagreb. Croatia (2003) reports that all public 
libraries now have these rooms. Also worth citing are the reports by Sweden (1998) and Spain (2001), because they indicate that when a child's illness forces them to be admitted into a hospital, it is possible to set up spaces adapted to children which allow them to exercise their right to play.

- There is a concern regarding the loss of green spaces that allow children to play outdoors and in nature (Norway, 1998 and 2004; Canada, 2003).

After the survey of the reports, we shall now share the content analysis of the $10 \%$ of the Final Observations which did refer to article 31 . The following issues can be taken into consideration:

- The lack of recommendations for families and the virtual irrelevancy of comments in the area of school, given that only in a few Final Observations for Japan (2010) did the CRC express its concern with the tensions generated in child development by the existence of an extremely competitive educational system which leaves little room for free time, physical activity and rest.

- The social sphere is where the CRC formulates the widest range of recommendations for the States Parties:

- In the Final Observations for Greece (2012), the Committee is concerned with the failure to adopt measures that protect children and adolescents from harmful information in relation to commercial products that can appear in toys, computer games and Internet programmes.

- In the Final Observations for Austria (2012), it recommends that the state enact laws to control light child labour when the school day is over, particularly in family businesses, in order to ensure the right to play, rest and free time.

- In the Final Observations for Belgium (2010), it notes the insufficiency of playgrounds and informal gathering and recreational space, particularly in rural and remote places. Likewise, in its Final Observations for Ireland (2006), it expresses its concern with the scant political and financial importance given to creating free-time facilities and with the fact that the increasing demand for housing may hinder the creation of public play areas.

- It asks the United Kingdom (2008), Romania (2009) and Belgium (2010) to make an effort to ensure that children with disabilities have appropriate play areas where they can engage in free-time and leisure activities. In the Final Observations for Belgium (2010), it is also concerned that children from disadvantaged families, as well as those who require psychiatric care, may be deprived to access to a full range of free-time activities.

- On the one hand, it notes with unease and observes with concern that in Romania $(2001,2006)$ the state has not paid enough attention to article 31 . On the other hand, it expresses its satisfaction with initiatives such as the National Play Policy in Ireland (2006) and the fact that the United Kingdom (2008) has the highest investment in the history of the central government of fostering child's 
play within The Children's Plan of England. Regardless the Committee recommends -such as for Japan (2010)- that the states support initiatives that promote and facilitate independent play among children in public spaces, schools and households.

\subsection{Second Period of Study: Reports and Final Observations Issued Between 2013 and 2017}

From the approval of General Observation No. 17 (April 2013) until 31 December 2017, the second period studied, a total of 78 reports were submitted by the States Parties that have ratified the Convention. However, $69.23 \%$ of the reports lack a single mention of the child's right to play.

After subjecting the content of the reports to a qualitative analysis, when referring to the child's right to play, the States Parties state that:

- They do not pay any attention to this right. In this sense, we can cite the reports from Santa Lucia (2013), Ethiopia (2013) and Honduras (2014). The report from Ethiopia is utterly sincere and states that this is due to the lack of resources, the low level of community participation and the lack of recognition of this need. The Honduran report is also quite clear and openly states the need for national public policies to improve inter-institutional and inter-sector articulation, to be allocated more economic and human resources and to extend to all the communities and children in the country, particularly in rural areas.

- Despite theoretically recognising its importance, in practice Turkmenistan (2013), Zambia (2015) and the Maldives (2105) do not push for either measures or actions that foster it. The latter believes that play should not be considered a luxury, but it states that the potential offered by free-time and recreational activities is not used sufficiently, and it does not conceal the fact that children spend much of their free time inside their homes playing electronic games or watching television.

- There is no measure, action, or state initiative that fosters play within the family.

- With regard to schools, several reports contain relevant points:

- The report from Singapore (2017) stresses the importance of recognising leisure and play in the school curriculum. However, the report from Vanuatu (2016) expands and further explores this aspect by considering that early childhood care and education call for principles and policy guidelines on recreational equipment and materials. In this way, children can play on adapted facilities and equipment and have the opportunity investigate, experiment, discover and solve problems within a situation of play.

- In terms of free-time facilities and school recreation, the report from Lesotho (2017) indicates that when the government improved the country's infrastructure, it attached due importance to including recreational spaces and facilities within schools. The report from Gambia (2014) states that all schools should 
have such spaces and facilities so that students can practise sports or other freetime activities. Not only does the report from Palau (2017) indicate the percentage of children who participate in organised activities, it also reflects on the importance of these spaces of play by recognising that playgrounds were not traditionally recognised since children were assigned household tasks and chores. The school system has introduced the promotion of organised activities and has turned playgrounds into spaces where children interact, meet other children and learn from each other.

- The reports from Nepal (2014), Ghana (2014) and Zambia (2015) indicate that recreational time at school has been established and regulated.

- The report from the Netherlands (2014) shows the increase in the number of community schools (around 1,500 out of approximately 6,500 primary schools) that hold activities before and after school. These activities include play groups.

- In the social sphere, the reports reveal a wide range of situations:

- The report from Ghana (2014) mentions the concern with the lack of public play areas and indicates that it is ironic that children in rural zones have enough room to play but no toys, while children in urban areas have toys but often lack spaces where they can play. The report from Bangladesh (2014) openly recognises that many poor and disadvantaged children continue to be deprived of opportunities for leisure, recreation, games and cultural activities.

- Conversely, the reports from Maldives (2015), Lebanon (2016), Belgium (2017) and Italy (2017) report on the creation or intention to create public spaces equipped with safe, inclusive games. The report from Ireland (2015) stands out by stating the existence of a national plan to create or improve playgrounds and the fact that local authorities have established policies on play.

- One way of increasing the public play areas is the one contained in the report from Brazil (2014) with the existence of the Escola Aberta programme. Its goal is to make the public primary and secondary school located in urban regions afflicted by violence and social vulnerability available to the entire community at weekends. This same initiative is being carried out in Japan (2017), but play may not fit into these spaces since, as gleaned from its report, activities like learning, interacting with nature and cultural, artistic, sport and other kinds of activities are held in the open Japanese playgrounds. However, there is no reference to play.

- Another interesting aspect worth bearing in mind is related to the use and enjoyment of free time. The report from the Netherlands (2014) refers to the lack of free time among youths. The report from the Solomon Islands (2017) reveals that children complain about a lack of free time because they have to spend that time on household chores and homework. Coupled with this lack of time is the problem of how it is used. The report from Mongolia (2016) warns about the fact that the main place where adolescents and youths spend their time is virtual gaming centres. 
During this second phase of the study (2013-2017), the CRC has issued a total of 96 Final Observations to the same number of States Parties. In $72.91 \%$ of the Final Observations, the CRC has not issued an opinion on the child's right to play. Only in $21.87 \%$ of the Final Observations does the CRC refer explicitly and directly to General Observation No. 17, while in the remaining $5.22 \%$ of Final Observations the Committee does mention article 31.

A qualitative comparative analysis of the Final Observations issued by the Committee leads us to point out that:

- Recommendations or observations for the States Parties in reference to the child's right to play within the family are non-existent.

- $\mathrm{t}$ school, the Committee is profoundly concerned -Iran (2016) and Maldives (2016)with discrimination against girls because they have a very limited right to participate in free-time and leisure activities, both inside and outside school. In the Final Observations for Honduras (2015), the Committee further fleshes out this standard by indicating that the few spaces available for recreation in this country lack a gender perspective and often exclude girls. In addition to the recommendation to provide recreational spaces both inside and outside schools -Honduras (2015)- the Committee also suggests -Gambia (2015)- that schools offer children sports, leisure and cultural activities.

- In the social sphere, the Committee makes a range of observations:

- In the Final Observations for Venezuela (2015), Tajikistan (2017), Bhutan (2017) and the Democratic Republic of Korea (2017), it recommends that the state should guarantee the implementation of policies on play and leisure which are allocated sufficient, sustainable resources, and which provide for time and spaces so that children can participate in play and in the recreational activities of their choice.

- It encourages Uruguay (2015), the Dominican Republic (2015), Chile (2015) and New Zealand (2017) to take the measures needed to ensure that all children, without exception, including adolescents, have access to a public space that is appropriate for play and recreational, cultural and sports activities, while it asks Yemen (2014) to guarantee that children have play time after school and on vacation.

- It encourages the United Kingdom and Northern Ireland (2016) and Ecuador (2017) to hold consultations with the goal of getting children fully involved in the planning, formulation and monitoring of the implementation of policies on play and free time at the community, local and national level.

In short, on the one hand, the Committee celebrates the initiative of the government of Wales -United Kingdom and Northern Ireland (2016)- to adopt a policy on play which includes the child's right to play in the relevant legislation, while on the other hand it recommends that Indonesia (2014) pay due attention to this right. To do so, the States Parties 
-as the Committee requests of Bangladesh (2015)- should assign all the human, technical and financial resources needed to initiatives that promote and facilitate children's play time in public spaces, schools and homes.

\section{DISCUSSION}

For the time being, the entry into force of General Observation No. 17 has not led to a significant change in which the States Parties' pay greater attention to the child's right to play. The Committee has slightly increased the number of recommendations, but it still draws the States Parties' attention to the need to comply with article 31 in a very limited way.

The international scene tells us that there are some countries with good practices (Germany, Austria, Belgium, Canada, Ireland, Netherlands, Sweden and United Kingdom), but based on the reports and Final Observations, the majority of the States Parties violate the obligation to fulfil article 31 . To make matters worse, there are states that openly recognise that they do not pay attention to this right due to a lack of recognition of this need (Ethiopia, 2013).

The reports have shown the little prominence and consideration given to play in the family. In school, the establishment and regulation of school recreational time and having better free-time facilities are achievements. However, oftentimes schools lack inclusive playgrounds. Furthermore, little importance is attached to independent play in educational systems and plans. The social sphere is where most initiatives have taken place. The spectrum of situations is broad, from States Parties that are sensitive to the importance of this right to others that do not pay it sufficient attention. It is very common for leisure policies not to take account of the states' child policies, and thus legislative and financial measures are lacking.

The reports primarily cite play areas. However, there are few references to playtime, and even less mention is made of play materials and playmates. Play should be viewed holistically because having the right spaces may foster it, but they do not guarantee child play, which requires time, materials and playmates to reinforce free-time activity.

One essential factor that cannot be ignored is that the States Parties provide information without making it fully clear whether they are achievements or statements of intentions. There are virtually no comments on laws and regulations that encourage, finance or regulate the child's right to play. The reports primarily point out measures and actions, but the plans and projects within which they should be framed in order to foster and develop them are described in a highly ambiguous fashion, and if the processes are not clearly shown, the results achieved cannot be reported in a clear, transparent fashion.

Proof of this is, for example, the fact that in the guidelines on drafting the reports, the States Parties are asked to report on the number/percentage of children in extracurricular activities; on the number of public playgrounds in the communities and whether they are in rural or urban settings; and on the number/percentage of children who participate in organised leisure, sports, cultural and artistic activities, and whether they are in rural or 
urban settings. However, despite the obligation to do this, the States Parties provide no statistical information.

Furthermore, two of them refer to extracurricular and organised activities, which is far from article 31's intention to promote autonomous play unsupervised by adults. Despite this observation, the guidelines do have indicators. However, it may be questionable whether three indicators are enough, because "to improve something you have to first measure it" (Adamson, 2007, p. 3).

One of the first experiments with indicators is the one promoted by the Annie E. Casey Foundation (1990) with the publication of an annual report entitled Kids Count Data Book on child welfare in the United States. A significant leap in terms of the need to evaluate using indicators was taken when the CRC (2003), in the General Measures to Implement the Convention, proclaimed the urgency of gathering sufficient, reliable data on children which encompasses all of childhood until the age of 18 , as well as including the monitoring mechanisms which make it possible to prove the enforcement of the rights within the evaluation system itself. A quick response to the CRC's call was presented in the study by Ochaíta and Espinosa (2004) which proposed different basic dimensions of the indicators on child welfare. In 2006, UNICEF's Innocenti Research Centre developed a system of child welfare indicators, and this proposal was further specified one year later in Report Card 7 (Adamson, 2007). Another reference is the European Union Agency for Fundamental Rights (FRA) proposal for a system of indicators on the protection, respect and promotion of the rights of the child in the EU (FRA, 2009). In parallel, several years ago the International Society for Childhood Indicators (ISCI) launched a working group, in conjunction with UNICEF among its promoters, with the purpose of encouraging the collection of international data among children aged 8,10 and 12. The specific objective of that project, called “The International Survey of Children's Well-Being” (ISCWeB), is to gather reliable, representative data on the lives of children and their everyday activities, their use of time and particularly their perception of their own wellbeing. Within Europe, Bradshaw and Richardson (2009) use seven dimensions to organise the indicators: education, health, material resources, family and social setting, behaviours and risks, personal relationships and subjective wellbeing. Therefore, as Ben-Arieh (2008) notes, we can see a gradual increase in the scholarly literature on childhood and adolescence, such that the descriptor "child indicators" is appearing more frequently in scholarly databases. Furthermore, the aforementioned International Society for Child Indicators (ISCI) has an international journal entitled Child Indicators Research (CIR). Therefore, we can claim that "The Child Indicators Movement" is gradually gaining momentum.

However, the indicators referring to free-time activity are absent or only barely present in scholarly or academic studies (Corona \& Gülgönen, 2013; Tuñon, 2014), in state statistical data and in plans, programmes and actions on policies for children. This absence confirms not only the need to promote the recognition of children's universal right to play but also the urgency of having an effective tool -such as the formulation of a system of indicatorsto evaluate it. 


\section{CONCLUSIONS}

Policies in favour of children in which play is ignored cannot be developed. It is indeed possible to cite other priorities or urgencies, but it still makes no sense because the ones who most need to have play as a major ally to contribute to their development are the most disadvantaged children, the most vulnerable ones, the ones who live in poverty, who grow without the care of their parents, who suffer from various kinds of exploitation, violence, abuse or mistreatment.

The lack of play in under-developed countries where children are largely faceless is mentioned repeatedly. However, albeit in a very different way, the welfare society often skews compliance with the right to play based on the lack of time for play by prioritising extracurricular activities, pressure from parents or the lack of places to play, just to cite a few of the most common problems. Identifying the difficulties in exercising this right in advanced societies is also a challenge.

By managing to formulate a system of indicators to evaluate recognition of the child's right to play (Payà \& Bantulà, 2019), it will be possible to have benchmarks or points of reference to monitor compliance with this right, enable it to be evaluated and suggest both the inclusion of indicators of child play in indices and indicators of childhood and ensure that play is part of the objectives, goals and strategies of the action plans in favour of children.

\section{ACKNOWLEDGEMENTS}

Funded by: Ministry of Economy and Competitiveness, Spain

Funder Identifier: http://dx.doi.org/10.13039/501100003329

Award: EDU2014-52268-P

\section{REFERENCES}

Adamson, P. (2007). Pobreza infantil en perspectiva: Un panorama del bienestar infantil en los países ricos. UNICEF.

Bantulà, J., \& Payà, A. (2020a). Jugar. Un derecho de la infancia. Graó.

Bantulà, J., \& Payà, A. (2020b). The right of the child to play in the national reports submitted to the Committee on the Rights of the Child. International Journal of Play, 9(4), 400-413. https://doi.org/10.1080/21594937.2020.1843803

Ben-Arieh, A. (2008). The Child Indicators Movement: Past, Present, and Future. Child Indicators Research, 1(1), 3-16. https://doi.org/10.1007/s12187-007-9003-1

Bradshaw, J., \& Richardson, D. (2009). An Index of Child Well-Being in Europe. Child Indicators Research, 2(3), 319-351. https://doi.org/10.1007/s12187-009-9037-7

Brooker, L., \& Woodhead, M. (2013). The Right to Play. Early Childhood in Focus (Vol. 9). Maidenhead: Open University.

Canning, N. (2007). Children's empowerment in play. European Early Childhood Education Research Journal, 15(2), 227-236. https://doi.org/10.1080/13502930701320966

Committee on the Rights of the Child (CRC). (2013). General comment No. 17 on the right of the child to rest, leisure, play, recreational activities, cultural life and the arts (art. 31). United Nations. 
Corona, Y., \& Gülgönen, T. (2013). El derecho de los niños and niñas al juego en México. Resultados de las consultas a niños, niñas and adultos. Rayuela. Revista Iberoamericana sobre niñez and juventud en lucha por sus derechos, 8, 103-111.

Dávila, P., \& Naya, L. M. (2006). La Evolución de los Derechos de la Infancia: Una Visión Internacional. Encounters/Encuentros/Rencontres on Education, 7, 71-93. https://doi.org/10.15572/ enco2006.04

Engel, M. (2015). The Importance of Free Play in the Early Childhood Classroom: Perspectives from a Teacher. Childhood Education, 91(5), 323-324.

European Union Agency for Fundamental Rights, FRA. (2009). Developing indicators for the protection, respect and promotion of the rights of the child in the European Union. Retrieved from http://fra.europa.eu/fraWebsite/attachments/RightsofChild_summary-report_en.pdf

Fronczek, V. (2009). Article 31: A 'Forgotten Article of the UNCRC'. Early Child-hood Matters. Early Childhood Matters, 113, 24-28.

Ginsburg, K. (2007). The importance of play in promoting healthy child develop-ment and maintaining strong parent bonds. Pediatrics, 119(1), 182-191. https://doi.org/10.1542/peds.2006-2697

Gleave, J., \& Cole-Hamilton, I. (2012). A world without play. A literature review of the effects of a lack of play on children's lives. Play England.

Goldstein, J. (2012). Play in children's development, health and well-being. Toy Industries of Europe (TIE).

Hodgkin, R., \& Newell, P. (2007). Implementation Handbook for the Convention on the Rights of the Child. UNICEF. Retrieved from https://digitallibrary.un.org/record/620060

IPA. (2010). Promoting the Child's Right to Play: IPA Global Consultations on Children's Right to Play Report. Faringdon.

Kernan, M. (2007). Play as a context for Early Learning and Development. NCCA.

Lester, S., \& Russell, W. (2008). Play for a Change - Play, Policy and Practice: A review of contemporary perspectives. Play England.

Lester, S., \& Russell, W. (2010). Children's Right to Play: An examination of the importance of play in the lives of children worldwide. Bernard van Leer Foundation.

Little, H., Wyver, S., \& Gibson, F. (2011). The influence of play context and adult attitudes on young children's physical risk-taking during outdoor play. European Early Childhood Education Research Journal, 19(1), 113-131. https://doi.org/10.1080/1350293x.2011.548959

Manwaring, B., \& Taylor, C. (2007). The benefits of play and playwork. CYWU/SkillsActive.

Meire, J. (2007). Qualitative research on children's play: a review of recent literature. Several Perspectives on Children's Play. Garant.

Milteer, R. M., Ginsburg, K. R., \& Mulligan, D. A. (2012). The Importance of Play in Promoting Healthy Child Development and Maintaining Strong Parent-Child Bond: Focus on Children in Poverty. Pediatrics, 129(1), e204-e213. https://doi.org/10.1542/peds.2011-2953

Moyles, J. (2010). Thinking about play: developing a reflective approach: Developing a Reflective Approach. Open University Press.

Navidi, U. (2016). The Role of Play in Children's Health and Development. MDPI.

Ochaíta, E., \& Espinosa, M. A. (2004). Hacia una teoría de las necesidades infantiles and adolescentes. Necesidades and derechos en el marco de la Conven-ción de Naciones Unidas sobre los derechos del niño. McGraw-Hill.

Payà, A., \& Bantulà, J. (2019). Building a System of Indicators to Evaluate the Right of a Child to Play. Children \& Society, 33(1), 13-23. https://doi.org/10.1111/chso.12291

Pramling, I., \& Asplund, M. (2008). The Playing Learning Child: Towards a pedagogy of early childhood. Scandinavian Journal of Educational Research, 52(6), 623-641. https://doi.org/ 10.1080/00313830802497265 
Sandberg, A., \& Heden, R. (2011). Play's importance in school. Education 3-13, 39, 317-329. https://doi.org/10.1080/03004270903530441

Sandseter, E. B. H. (2007). Categorising risky play-how can we identify risk-taking in children's play? European Early Childhood Education Research Journal, 15(2), 237-252. https://doi.org/ $10.1080 / 13502930701321733$

Tonkin, A. (2014). The provision of play in health service delivery. Fulfilling children's rights under Article 31 of the United Nations Convention on the Rights of the Child. A literature review.

Tuñon, I. (2014). Entre el tiempo escolar, los amigos and el espacio público. Niños/as entre 5 and 17 años en la Argentina urbana. Observatorio de la Deuda Social Argentina, Barómetro de la Deuda social de la Infancia.

UNICEF Innocenti Research Centre. (2004). Summary report of the study on the impact of the implementation of the convention on the rights of the child.

White, R. (2012). The power of play. A research summary on play and learning. Children's Museum.

Whitebread, D. (2012). The importance of play. A report on the value of children's play with a series of policy recommendations. Toy Industries of Europe (TIE). 